\title{
Sports Adventure: Goals Orientation in the Rafting Practitioners
}

\author{
Derlis Augusto \\ Department of Physical Education - Nossa Cidade-Estácio College - São Paulo, Brazil. \\ Felipe Souza de Almeida \\ Department of Physical Education - Nossa Cidade-Estácio College - São Paulo, Brazil. \\ Lucas De Andrade Guedes Barros \\ Department of Physical Education - Nossa Cidade-Estácio College - São Paulo, Brazil. \\ Carlos Eduardo Lopes Verardi
}

Sciences College - Department of Physical Education - UNESP - Baurú, Brazil. Vinicius Barroso Hirota

Department of Physical Education - Mackenzie Presbyterian University and Nossa Cidade-Estácio College, São Paulo, Brazil.

\begin{abstract}
We aimed in this study to observe what kind of motivational goal's orientation the rafters and testing an instrument of motivation. As a descriptive study we applied the TEOSQ instrument in a 20 rafting participant's ( $n: 20$, mean age $26.20 \pm 4.40$ ), male and female, and as statistical procedures we calculate the Alphas Coefficient, the average, median and standard deviation of each goal orientation, and for correlation we adopted que spearman correlation and for difference between mean the Mann-Whitney test.The results showed a good reliability of the instrument (Alpha of task: 0.72 and ego orientation: 0.80 ), there were no difference between gender in both goal orientation, but the prevalence was the task orientation, so these kind of Brazilian's rafters want to work hard, enjoy the challenger and always trying to perform their self's better by training more.
\end{abstract}

Keywords: Rafting; Motivation; Goal's Orientation; Adventure Sport.

\section{INTRODUCTION}

As today, rafting and many other radical forms of contact with nature has attracted thousands of people of both genders and various ages to practice on the weekends (Marchi and Mezzadri, 2003).Thus, Paixão and Menezes (2009) says that rafting which is to go the rapids of a river in inflatable boats.

According to Marchi and Mezzadri (2003) rafting is practiced with inflatable rubber boats, in the boat there is a guide or instructor and canoeists, each boat has six to eight athletes who paddle in harmony to meet the challenge from the rapids, divided in 3 modes: descent, rescue and slalom.

For Moreira and Parade (2005) the rafting is an activity both recreational as sportive. It requires equipment, knowledge, technical preparation and logistics for its implementation, but it can be easily popularized in areas with high incidence of river resources.

The possibility of offering the man unique experiences and cause sensations and little experienced emotions, and develop in some cases teamwork and self-confidence are some of the main features of these practices, which are still poorly explored in the academic context of different related fields (Carnicelli Filho and Schwartz, 2005).

Therefore, activities with different physical and recreational conceptions of traditional sport, without rules or institutionalization, varying degrees of motivation of practitioners, practice conditions, the means used to its full development adventure (Betran and Bretan, 1995).

Thus, enhance the motivation and teamwork betting that this sport can improve communication skills among staff and personal self-confidence, makes the practice of sports such as rafting tends to grow (Sato and Spricigo, 2008). 
So we believe that motivation is crucial to the practice of rafting since the pursuit of challenge in this mode, to be classified as adventure sports, enables us to find ourselves with the unexpected. As Moretti and Treichel (2003) points out that the human being brings with it feelings, ambitions; creates expectations, it engages seeks growth within what develops and performs.

Hirota et al. (2012) emphasize that the elements of the environment, along with the momentary situations lead an individual to perform or not a particular action. Within this context, overcoming the possibilities due to intermittency characterized the sport can make practitioners demonstrate aspects related to self-determination and reworking of their motor skills, is readapting to the challenges, always seeking self-realization in context.

Mosquera and Stobäus (2006) say that people who have a tendency to self-realization, he even differentiate the environment, in particular through transactions and transitions it. Gouvea (1997) adds that people who have a high level of achievement motivation demonstrate, through words and actions, a search by the standard of excellence. For a coach, this individual in the competition would have as its goal the success and better sports performance.

Lavoura and Machado (2006) say that athletes considered more technical or more skillful better realize their ability to assess their conditions of performing successfully a certain action. The realization of reason is often considered a growth of reason (Paim, 2001).

Thus, the theory of goals achievement (Nicholls, 1984, 1989) assumes that individuals are guided by objectives and active rationally, suggesting that individuals can guide their motivation in two ways (guidance to ego and orientation tasks), depending on the criteria by which they evaluate their competence and define the success of their participation in a particular activity, in a context of achievement.

Ego orientation is relate when a person is oriented mainly to show more income than the other, and the guidance to task orientation people linked to learn or to perform a task with skill, i.e., search itself overcome (Duda, 1993).

Emotional expression practitioners may differ depending on the cultural situations, the motivational components and the states of momentary mood and, in the case of adventure activities are associated with the concepts of risk and security activities offer (Schwartz and Carnicelli Filho, 2006).

Due to this problem of motivational reflection practice of adventures sports we aimed in this study to observe what kind of motivational goal's orientation the rafters and testing an instrument of motivation.

\section{METHOD}

This work was characterized as a descriptive (GIL, 1995). A total of 20 participants $(n=20)$ age between 20 and 36 years (mean age $26.20 \pm 4.40,16.77 \%$ coefficient of variation), composed the study. Of this total 14 men of average age of 27 years $( \pm 4.49,17.00 \%$ variation coefficient $)$ and 6 women of average age of 24.33 years $( \pm 3.88$, variation coefficient of $15.95 \%)$, so the data presented were homogeneous in relation to age of the study participants. The sample consisted of convenience and the established criterion was that all participants were adults and practiced the sport for more than 3 years; they signed the free and informed consent form, which was taken at the site of research, ie in one of the rapids, and a final pre week established by the researchers, this way all ethical considerations in research were taken.

The instrument applied was Task and Ego Orientation in Sport Questionnaire (TEOSQ) developed by Duda (1992), translated, adapted and validated for Portuguese (Brazil) by Hirota et al. (2006) and Hirota and De Marco (2006) among other studies. The purpose of TEOSQ is to assess individual differences in perspectives of the goal, set the practice of school sports, detecting whether the individual is determined to be task-oriented or ego (DUDA, 1992). This instrument allows you to identify the motivational orientation of athletes against execution of a task, namely, respondents must be seen against the sport training and assess how successful he finds himself in this mode. The TEOSQ consists of 13 Likert questions of 5 points (varying according to the level of agreement with each of them), and 06 issues orientation to ego or afraid of failure (answers ranging from 6 to 30 points score), and 07 issues of task orientation or expectation of success (responses ranging from 7 to 30 points in the score). The unfastened time to answer the instrument is approximately 5 minutes, and this self-report instrument.

We adopted as statistical analysis calculating Cronbach's Alpha coefficient in order to confirm the reliability of the scale, instruments still untested in canoeing and rafting, by putting proof the 
legitimacy of the front instrument to the subjects involved in the study. In order to watch potential significant differences between the means of task and ego goals, we decided to make the MannWhitney test with significance level of $p=0.05$, separately for each orientation, i.e., orientation task and goal orientation ego goal, remembering the possible existence or not of significant differences between genders. In addition, correlation was calculated using Spearman correlation (rho) with significance level of $p \leq 0.05$ for all the calculations

\section{RESUlTS AND DISCUSSION}

Orientation alpha's coefficient result for ego 0.80; concerning the orientation of 0.72 task. Thus demonstrating stability in the internal consistency of the items in this way, we can say that compared to other studies with the same instrument in Brazil (Hirota and Marco, 2006; Hirota, 2014; Costa et al, 2015; Hirota et al. 2015; Albuquerque et al, 2015; Anjos et al, 2015), continues to demonstrate consistent results across the alpha coefficient. There is no minimum value set for the Cronbach's alpha coefficient is accepted as good, but finds in the literature the value of 0.70 as acceptable minimum (Freitas and Rodrigues, 2005)formerly cited by Hair et al. (2005) as a reference value adopted as acceptable is equal or greater than 0.60. Therefore, Cronbach's alpha determines whether the scale is truly reliable, because it assesses how each item reflects its reliability (Salomi et al, 2005).

Going into the results that the instrument offers us, we find that task orientation average for total group was at $4.50( \pm 0.64)$, a result higher in females $(4.57 \pm 0.59)$ than in male $(4.46 \pm 0.66)$, however there was no significant difference between the means, so the result is presented homogeneous (see Table 01).

Table01. Average Results, Median Score and the Difference between Means Of Each Motivational Orientation

\begin{tabular}{|c|c|c|c|c|c|c|c|c|}
\hline \multirow{3}{*}{ Gender } & \multicolumn{8}{|c|}{ ORIENTATION } \\
\hline & \multicolumn{4}{|c|}{ TASK } & \multicolumn{4}{|c|}{ EGO } \\
\hline & Average ( \pm$)$ & "p" & med. & Score & $\operatorname{Media}( \pm)$ & "p" & med. & Score \\
\hline Male & $4,46 \pm 0,66^{*}$ & \multirow[t]{2}{*}{$* 0,257$} & 5 & 31,28 & $2,26 \pm 0,91 *$ & \multirow[t]{2}{*}{$* 0,130$} & 2 & 13,57 \\
\hline Female & $4,57 \pm 0,59 *$ & & 5 & 27,43 & $2,00 \pm 0,86^{*}$ & & 2 & 12,00 \\
\hline Total & $4,50 \pm 0,64$ & & 5 & 31,50 & $2,18 \pm 0,90$ & & 2 & 13,10 \\
\hline
\end{tabular}

In guiding questions for the ego the total average of the group was $2.18( \pm 0.90)$, and these issues men (2.26 \pm 0.91$)$ had higher average than women $(2.00 \pm 0.86)$, but when comparing the mean the results was not significant, thus regarding the motivational orientation for ego also both genders have equal media.

All orientation medians for task were 5 points, maximum value, and away from the orientation to the ego which was 2, thus demonstrating that the total group and in both genders, the orientation task is predominant.

Scores for males were higher task following the average trend; the same result was with the orientation to the ego, so men have ego bigger score than women, but not significant. These results were confirmed when orientation means were compared to and task, thus demonstrating that the male and female predominance of the result of higher motivational orientation is task ( $p=0.001$ for both).

When establish the correlation between data, or correlated with orientation task and ego noted that the results showed a weak positive correlation, however significant ( $r h o=0.188, p=0.03$ ) and thus as orientation task tends to increase orientation also for ego, but weak and dispersed manner, and thus, this correlation demonstrates the orientation feature for task.

The emotions in this sport certainly change constantly, because, every day, the routine activity was altered by natural and social factors. This means that each group down the chute are provided different times for the guides, is the spirit of adventure, that is, the natural conditions of the location of the activity (Carnicelli Filho and Schwartz, 2005)

Control of the emotions is essential for practitioners to act decisively in overcoming unexpected situations, making it necessary awareness of these elements in the professional commitment, because it affects, including aspects related to the motivation of users to overcome their limits, facing stakeholder's fears in practice; the "rafting" differs from other adventure sports to be practiced in fluvial environment and be carried out in teams (Schwartz and Carnicelli Filho, 2006).

According to Nicholls (1989), variations to achieve fulfillment of people correspond to changes in their way of understanding the contexts that surround them, especially as to the meaning and function of their performance of activities. 
Thus people with characteristics oriented to task, seek activities consistent with your level, or to be more persistent will seek to achieve variations within the proposed task.

Thus, the perception of competence tends to be self-referred, if the individual is task-oriented. On the other hand, when an orientation ego prevails, people tend to be concerned about their ability and see a personal demonstration of superior quality as a key to success. Oriented individuals to ego tend to judge their own competence in relation to others (Castillo et al., 2009).

As stated Fonseca and Brito (2001), athlete's task oriented feel more successful when they demonstrate clear improvement in my performance, and oriented to the ego, they feel most successful when they defeat their opponents.

However, the theory goal orientation, which was based on the theory of self-realization, assuming that people vary in how they define achievement and judge your self-perception of perceived competence. Individual goal perspective influences the way one thinks, feels and acts in achievement situations, such as education and sports (Nicholls, 1984). For this reason, a small variation in the results can be found.

We conclude that presently the preconception is decreasing, but still exists. It has been proven that many athletes still suffer from prejudice, are targets of jokes and have no place in the media.

\section{Conclusion}

We believe that the instrument showed a good internal consistency of performance, Alfa result stability, and thus may be replicated in this sport, however taking into consideration increase of participants in future studies. We also believe that the profile of motivational orientation goal for task reflects practitioners who are persistent, most accept the challenges that are often unpredictable in the rapids that offers rafting because we are in direct contact with the forces of nature.

\section{REFERENCES}

[1] Marchi KB,Mezzadri FM. História da canoagem e do rafting. In: ANPUH - XXII Simpósio Nacional De História - João Pessoa(2003).

[2] PaixãoJA,Menezes VLC. Esporte de aventura e turismo de aventura: aproximações e distanciamentos. Lecturas: Educación física y deportes, 139(2009).

[3] Moreira JCC,Parada K. Canoagem: análise cinesiológica da remada básica. Lecturas: Educación física y deportes, 83, 28(2005).

[4] Carnicelli Filho S,Schwartz GM. Guias de Rafting: perfil e emoções. Lecturas: Educación física y deportes, 85, 21(2005).

[5] Betrán AO,Betrán JO. Propuesta de uma clssificación taxonômica de las actividades físicas de aventura em la natureza. Marco conceptual y análisis de los critérios elegidos In.: Dossier Las Actividades Físicas de Aventura en la Naturaleza: análisis sociocultural. Apunts: Educación Física y Deportes, Barcelona: Institut Nacional d'Educación Física de Catalunya, 41, 5-8(1995).

[6] Sato CF,Spricigo CB. Motivação refletindo na qualidade e produtividade. Visão Acadêmica, 9(1), 63-74 (2008).

[7] Moretti S,Treichel A. Qualidade de vida no trabalho x auto-realização humana. Revista Leonardo pós-Órgão de Divulgação Científica e Cultural do ICPG, Blumenau, 1(3), 73-80 (2003).

[8] Hirota VB,Verardi CEL, DeMarco A. Orientação motivacional de metas na modalidade do basquetebol. Educação Física em Revista (Brasília), 6, 1-9(2012).

[9] Mosquera JJM,Stobäus CD. Auto-imagem, auto-estima e auto-realização: qualidade de vida na universidade. Psicologia, saúde \& doenças, 7(1), 83-88 (2006).

[10] Gouvêa FC. Motivação e o esporte: uma análise inicial. In: Buriti MA. (Ed..) Psicologia no Esporte - Coleção Psicotemas. Campinas: Editora Alínea, 149-173 (1997).

[11] Lavoura TN,Machado AA. Esporte de aventura de rendimento e estados emocionais: relações entre ansiedade, autoconfiança e auto-eficácia. Motriz, Rio Claro, 12(2), 143-148 (2006).

[12] Nicholls JG. Achievement motivation: conceptions of ability, subjective experience, task choice, and performance. Psychological Review, 91(1984).

[13] Nicholls JG. Conceptions of ability and achievement motivation. In: Ames R,Ames C. (Eds.). Research on Motivation in education. Student Motivation, v. 01. New York: Academic Press(1989). 
[14] Duda JL. Goals: a social cognitive approach to the study of achievement motivation in sport. In: Singer RN,Murphy, M,Tennant LK. (Eds.). Handbook on research in sport psychology. New York: MacMillan(1993).

[15] Schwartz GM,Carnicelli Filho S. (Desin)Formação profissional e atividades de aventura: focalizando os guias de "Rafting". Revista Brasileira de Educação Física e Esporte, 20(2), 103109 (2006).

[16] Gil AC. Métodos e Técnicas de pesquisa social. São Paulo: Atlas, 1995.

[17] Duda JL. Motivation in Sport Settings: A Goal Perspective Approach. In Roberts GC.Motivation in Sport and exercise. Illinois: Human Kinetics Books (1992).

[18] Hirota VB, Schindler P, Villar V. Motivation in university athletes practicing female soccer field: a pilot study. Mackenzie Journal of Physical Education and Sports, 5(3), 135-142 (2006).

[19] Hirota VB, DeMarco A. Identificação do clima motivacional em escolas públicas e particulares na aprendizagem esportiva no futebol de campo: um estudo piloto. Revista Brasileira de Educação Física e Esporte, 20(5), 415(2006).

[20] Hirota VB. Goal orientation of Brazilian skateboarders. Journal of Physical Education and Sport Management, 5(1), 1-4 (2014).

[21] Costa CE,Hirota VB, DeMarco A. Motivational goals orientation in Physical Education classes of elementary education. Journal of Physical Education and Sport, 15(2), 167-171(2015).

[22] Hirota VB,Amurim ESS,Luna FOS,Braz L,Lopes KC. Achievement Goals Orientation of Brazilian Participant's of a Dance Festival. International Journal of Sports and Physical Education, 1(1), 29-34(2015).

[23] Albuquerque I,Diniz DV, DeFrança E,Paiano R,Hirota VB. Reliability of Teosq in Brazilian jiujitsu and muay-thai fighters: a pilot study. International Journal of Physical Education, Sports and Health, 1, 12-15(2015).

[24] Anjos RMM,Ferreira ENG,Silva DD,Paulo LFL,Hirota VB. Goals orientation and pre competitive stress of Brasilians track and field athletes. International Journal of Physical Education, Fitness and Sports, 4 1-9 (2015).

[25] Freitas ALP,Rodrigues SG. A avaliação da confiabilidade de questionários: uma análise utilizando o coeficiente alfa de Cronbach. XII SIMPEP, 1-15(2005).

[26] Hair JF,Anderson RE,Tatham RL,Black WC. Análise multivariada de dados. Porto Alegre (RS): Bookman, 89-127(2005).

[27] Salomi GGE et al., Servqual x Servperf: comparação entre instrumentos para avaliação da qualidade de serviços internos. Gestão da Produção, 12(2), 279-293 (2005).

[28] Castillo I,Tomás I,Balaguer, I,Fonseca AM,Dias C,Duda JL. The Task and Ego Orientation in Sport Questionnaire: Testing for Measurement Invariance and Latent Mean Differences in Spanish and Portuguese Adolescents. International Journal of Testing, 9, 21-32, (2009).

[29] Fonseca AM,Brito AP. Estudo exploratório e confirmatório à estrutura factorial da versão portuguesa do Perception of Success Questionnaire (POSQ). Revista Portuguesa de Ciências do Desporto, 1(3).(2001).

\section{AUTHORS' BIOGRAPHY}

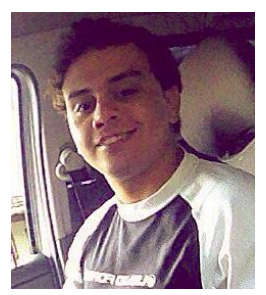

Derlis Augusto

Graduated in physical education

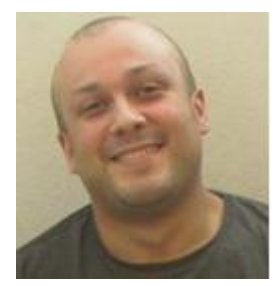

Felipe Souza de Almeida

Graduated in physical education 


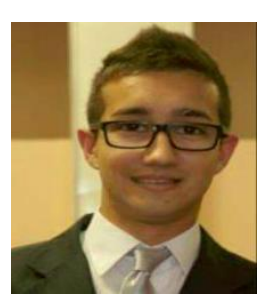

\section{Lucas De Andrade Guedes Barros}

Graduated in physical education

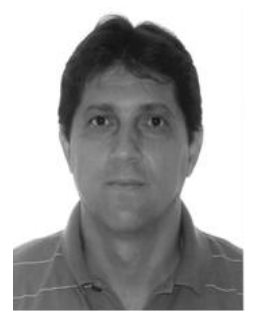

\section{Carlos Eduardo Lopes Verardi}

Graduated in physical education, Exercise Physiology specialization, Master in physical education and Doctorate in Health Sciences

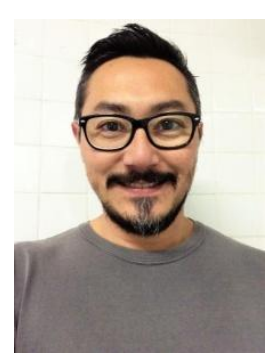

\section{Vinicius Barroso Hirota}

Graduated in physical education, Master in physical education and Doctor in development disorder; Researcher member of the Brazilian Paralympic Academy and ITO - International Technical official of the International Paralympic Committee. 